F. Kopfchirurgie

Mittwoch, 6. April 1983

\title{
189. Fehler und Gefahren bei der Erstbehandlung von Patienten mit schweren Kopfverletzungen
}

\author{
H. Scheunemann, K. Schürmann, A. Nover und J. Helms
}

Klinik für Mund-, Kiefer- und Gesichtschirurgie, Neurochirurgische Klinik, Augenklinik, HNO-Klinik, des Universitäts-Klinikums Mainz, Langenbeckstraße 1, D-6500 Mainz

\section{Error and Hazard in Early Treatment of Severe Injuries of the Head}

\begin{abstract}
Summary. The stabilisation of the vital function of blood supply and oxygenation of the brain by an anaesthesist is primary. If there is no severe intra- or extracranial bleeding we can begin immediately with the resposition of the middle face fractures before they become fixed with dislocation of the bony structures. Perforation of the eyeball should be treated quickly; early enucleation in severe cases is rarely justified. If there is a sharp neck injury with an open trachea, the patient may be saved by immediate intubation through the wound. In particularly severe cases with no open wound and major haematoma in the neck region, coniotomy is recommended to be undertaken immediately.
\end{abstract}

Key words: Intra-extracranial bleeding - Fractures of the middle face - Injuries of the eyeball and of the neck.

Zusammenfassung: Die Sicherstellung der vitalen Funktion von Atmung und Kreislauf ist vordergründig. Liegt keine intra- oder extrakranielle Blutung vor, so kann zunächst die Mittelgesichtsfraktur versorgt werden bevor diese in Fehlstellung knöchern verheilt. Akut ist die Versorgung einer perforierenden Verletzung des Augapfels, eine Frühenucleation eines schwerverletzten Auges ist nur in Ausnahmefällen gerechtfertigt. Bei scharfen Halstraumen mit Eröffnung der Trachea gelingt die Intubation und Beatmung des Patienten am schnellsten über das Wundgebiet, bei stumpfen Verletzungen ist eine Coniotomie eine wichtige Sofortmaßnahme.

Schlüsselwörter: Intra-, extrakranielle Blutung - Mittelgesichtsfrakturen - Bulbusverletzung - Halstrauma.

\section{Neurochirurgische Behandlung posttraumatischer intrakranieller Komplikationen}

\section{H. Dietz}

Neurochirurgische Klinik der Medizinischen Hochschule Hannover, Konstanty-Gutschow-Straße 8, D-3000 Hannover 61

\section{Neurosurgical Treatment of Posttraumatic Intracranial Complications}

Summary. Four possible complications after head injuries are discussed and their treatment is briefly outlined: the reactive brain edema, the intracranial hematoma, the fronto- and laterobasal head injury because of its traumatic communication between intradural space and the outside via paranasal sinuses, the direct lesion of brain and brain vessels through penetrating foreign bodies and bone splinters.

Key words: Head injury - Posttraumatic intracranial complications - Neurosurgical treatment.

Zusammenfassung: Es werden besonders vier Komplikationsmöglichkeiten nach Schädelhirnverletzungen herausgestellt und deren Behandlung kurz skizziert : das reaktive Hirnödem, das intrakranielle Hämatom, die traumatische Kommunikation zwischen Intraduralraum und Außenwelt über die Nasennebenhöhlen bei frontobasaler und laterobasaler Schädelhirnverletzung, die direkte Verletzung von Gehirn und Hirngefäßen durch penetrierende Fremdkörper und eindringende Knochensplitter.

Schliisselwörter: Schädelhirntrauma - Posttraumatische intrakranielle Komplikationen - Neurochirurgische Behandlung. 